\title{
The Discipline of Political Science: (Re)Positioning between Naïve Objectivity and Self-Destroying Pure Partisanship
}

\author{
Anton Pelinka \\ Central European University, Budapest \\ anton.pelinka@uibk.ac.at
}

\section{Introductory remarks}

This article is the result of some decades of experience: based on the disappointment of a student at the University of Vienna's law school, which offered a curriculum that - in the early 1960s - did nothing to satisfy the interests of a young Austrian, socialized in post-I945 Vienna. Nevertheless, there are certain things from the grey years of my law studies, for which I have to be grateful - the lectures of the sociologist August Maria Knoll; and the seminar-style "Pflichtübung" the young assistant professor Konrad Ginther offered in International Law. Yet, a true eye-opener was the lecture Heinz Eulau gave about the meaning of democracy at the Viennese Institute for Advanced studies in 1965/66. In the following years, conversations with many persons shaped my understanding of the discipline which became my discipline: talks with Norbert Leser during my Salzburg years, talks with American friends during my stays in New Orleans and Harvard, Stanford and Ann Arbor first and foremost with my special friend Andy Markovits. I was also influenced during the years when, beginning in 1975, I was privileged to establish our discipline at the University of Innsbruck. Permanent contacts with my Innsbruck colleagues were of significant importance for my thinking about political science, and so were the I2 years in the cosmopolitan atmosphere of the Central European University Budapest. All this can be summarized in one sentence: Political science is based on lifelong learning.

\section{Self-Determination: Privilege and Challenge}

Political science is what political scientists say - and what political scientists do. It is the privilege of any established academic discipline to enjoy the right of selfdetermination. This privilege is enshrined in the legal framework of Austrian and European universities as well as in the structure of a university like the University of Innsbruck, which has established curricula centred around political science as the core discipline, based on an institute (department) named after that discipline.

This privilege can be misunderstood as a final achievement which allows complacency among political scientists, teaching and doing research in such an institutionalized environment like a university department. This, of course, would be a complete misunderstanding. Especially for political scientists in a country like Austria, in which the discipline of political science has been delayed and its breakthrough within a rather unfriendly academic environment has been the product of political conflicts, the very existence of the - our - discipline in the realm of undisputed academic disciplines, among the traditionally "privileged" disciplines like philosophy or history or law, spares us not debating and discussing the necessarily complex and sometimes not so comfortable question: Why does our discipline exist? Which intellectual, academic as well as political function does political science fulfil?

Academic and especially intra-university autonomy cannot ignore different systems of references forcing any discipline to justify its doing. There is the competition within the university system - within one university, and within the national (and European) system of universities. And there is the necessity to be - formally, and perhaps even more important - informally evaluated and judged by international standards, by the results of international competition. "Peer reviewing" may be seen as self-evident or as bureaucratic burden - but it is the necessary help to prevent falling into the trap of academic routine.

We permanently have to answer the question of what political science is and, even more important, what it is not. We have to be aware of the permanently shifting border lines between different disciplines as well as the 
ongoing significant developments within the discipline. And we cannot ignore the question: What is the surplus value of our discipline - the value for academia and for the society at large? How can we justify the very existence of political science?

Can we rightfully argue that Austria's university would be of lesser quality without political science? Can we really argue that our discipline has to offer something of an improvement for the society? My answer tends to be "yes". But we should not take this answer automatically and permanently justified.

\section{The Delay of a Discipline}

Political science in Austria has been delayed. One reason was the "conservative backlash", Martin Senn and Franz Eder (2018) describe in their contribution; a backlash which had prevented the development of what Senn and Eder call political science's "pre-disciplinary phase". With the authoritarian rule, beginning in 1934, and the totalitarianism between 1938 and 1945, the academic realm has lost the freedom any social science needs for its very existence.

After 1945, the vested interests of the traditional academic establishment tended to bloc a discipline seen as a newcomer. The specific Austrian roots of the political science - e.g. Joseph Schumpeter's approach to understand politics (and democracy) as a market or Maria Jahoda's, Paul Lazarsfeld's and Hans Zeisel's Marienthal-study which followed more or less a concept of social psychology to understand the political consequences of an economic and social crisis - had been extinguished for years from academic and intellectual life in Austria. And, in a marked difference to post-1945 Germany, the liberating and occupying forces of the allies did not command and control - at least not directly (as they did in Germany) - a new academic beginning. For that reason, there was not much of a new beginning at Austrian universities in 1945 .

As it can be seen from its "pre-disciplinary phase", Austrian political science developed out of academic activities from academic researchers not educated as political scientists. The authors of "Die Arbeitslosen von Marienthal" were trained as psychologists. Joseph Schumpeter had started his academic career as professor of economics in imperial Austria's easternmost university, in Czernowitz, before he became republican Austria's first minister of finance - and before he, as professor at Harvard University, published his famous "Capitalism, Socialism, and Democracy", one of the most important books ever written in the field of political (as well as economic) theory. Austrian political science did exist - before the debate about its institutionalization as a social science among others began. And this debate did not start even immediately after 1945, when the Austrian universities were freed from the authoritarian and totalitarian restrictions. This debate started - looking back - surprisingly late.

Political science paid a price for this delay: From its start, in the I960s and I970s, political science's position was as at the periphery of the periphery. At the very centre of our discipline was political science as defined by the standards set by US-universities. Electoral research had to follow what had been developed at Columbia University or the University of Michigan. The standards of the study of international relations were defined by Johns Hopkins University and at Stanford University, and what Political Theory had to include followed the path of Universities of Harvard, Yale, and Chicago.

At the Institute for Advanced Studies in Vienna, where - beginning in 1963 - the Ford Foundation (following Paul Lazarsfeld's recommendation) sponsored the first systematic curricula in political science, USAmerican professors like Heinz Eulau or Dwaine Marvick influenced the first generation of Austrian political scientists, their first research and their first academic publications (see Stiefbold/Marvick 1966; Gerlich/ Kramer 1969). What US-political scientists said defined Austrian political scientists. When, at the beginning of the political academies of Austrian parties in the early I970s, the ÖVP inaugurated its academy it invited Karl Deutsch - one of the most prominent political scientists of his time and an American with Austrian roots - as keynote speaker for this opening. Austrian political science started on the periphery of a global discipline organized around a centre - US-political science.

But there was another centre, a centre in the periphery: (West-) Germany's political science offered career opportunities for Austrian political scientists. In the I970s (and the years to follow), German universities became the starting point of careers for Austrians; and the newly established discipline at Austrian universities was shaped, already beginning with the end of the 1960s, by German political scientists teaching in Austria. (West-) German political science, earlier developed due to the direct influence of the educational policies of the allies, had an immense impact on Austrian political science.

Among the first systematic analyses of Austrian politics were books written by US-American (Powell 1970, Steiner 1972, Bluhm 1973) and by West-German political scientists (Lehmbruch 1967, Nassmacher 1968). And the career of Gerald Stourzh offers an excellent example of that fruitful transnational and trans-disciplinary interdependence: Stourzh graduated with a $\mathrm{PhD}$ in history from the University of Vienna in I95I, studied as a postdoc ("research associate") at the University of Chicago with Hans J. Morgenthau (one of the most influential political scientists in the field of International Relations), became 1963 Professor for American History at 
the John F. Kennedy Institute of the Free University in (West-)Berlin - and, beginning with 1967, as professor of Modern History at the University of Vienna, he became (and still is) the number-one scholar when it comes to the analysis of Austria's international political position in the decade after 1945 (Stourzh 2009).

\section{How much Politics is in Political Science?}

Political science has to face an inbuilt challenge: it calls itself "political". That name "political" implies - rightfully, and of course intentionally - a link to politics. Political activists of different political persuasions have been attracted by the discipline: The interest in politics leads to an interest in political science. This has been especially the case in Austria in the I960s and I970s, when the - seemingly - exotic newness of the discipline motivated young people to see the study of political science as a way to become prepared and qualified for political careers, within or outside the established political system. Political science has been (and will be) a discipline associated with political emotions, with compassion, with empathy for a specific political agenda. But it would be wrong (despite being understandable) to interpret political science as a political instrument.

Any political motivation to study political science is, per se, a significant chance for the discipline: Political science is, for many, in a certain way "sexy". But the "sexiness" of the discipline implies also a danger: the mere academic study of political science can be misunderstood as part of a political agenda. Political science is, of course, not political activism in academic disguise. Political partisanship - welcome as a motivation for political science - must be separated from the academic discipline. If political partisanship and political science are getting mixed up, the academic acceptance of the discipline will be reduced; and, even more important, the discipline would be impaired in its main function: helping to understand politics as it is; and not as it should be. Political science teaches not political beliefs - and especially not one specific belief.

This makes it necessary to keep a balance: between the legitimate political activism of political scientists and the necessary distance between political science as an academic discipline; its academic research and teaching on the one side - and political activism on the other. As it can be seen in Eva Lichtenberger's contribution to this volume, keeping this kind of balance may be a difficult challenge but this balance can be kept. Nevertheless - it is a challenge that gives political science a kind of uniqueness among all the other disciplines within the family of social sciences: Studying economics or becoming a sociologist is not in the same sense or at least not in the same intensity linked to the temptation to side with a specific political agenda or with an approach to a specific school of thinking.

Teaching political science in the academic environment of a university means to underline two approaches which easily can be seen as a contradiction: on the one side, the discipline has to insist on its standards which guarantee its distance from partisanship in the most narrow sense - partisanship for a political party, for a specific agenda, for a specific policy; on the other side, within the discipline political activism must be respected - not only as respect for political pluralism but also to keep a specific motivation for the study of political science alive: the emotional interest in politics.

Political science has to confront false knowledge, knowledge not based on evidence, by de-constructing specific misleading concepts. Some examples: In cooperation with biological science, but focusing specifically on political implications, the term "race" has to be exposed as an ideology implanted on the political discourse following specific interests (Sowell 2013). Together with the efforts of sociologists, the concept of "people" hast to be de-constructed as either (by ethno-nationalism) highly ideological or defined as the summary of all citizens, following Robert A. Dahl. Dahl postulates the inclusion of all citizens, all persons living in a specific territory, in "the people" as a basic "categorical right" - independent from ethnicity and, of course, from religion and gender (Dahl I989, I22 - I24). And: Wishful thinking as a tendency, which seems to be the consequence of political partisanship, has to be destroyed - e.g. the popular (populist?) understanding that the highest level of political participation will always be the best guarantee for democratic stability.

In Seymour Martin Lipset's "Political Man", we will find significant evidence that the electoral turnout (as one indicator for political participation) is not correlated positively with democratic stability (Lipset I98I). And as Bernard Berelson, Paul Lazarsfeld, and William Mc Phee have demonstrated, the "Ideological Man", who is "absorbed in public affairs, highly partisan, rigid" is as dangerous for democratic stability as the "Sociable Man" is, who is "indifferent to public affairs, non-partisan, flexible" (Berelson/Lazarsfeld/McPhee 20I7, 47) Political science has to transmit the political reality - the reality, that any democratic system is best served by the "Political Man" who can be described to be interested in public affairs regularly and some of the time, but not permanently, and not all of the time.

To understand the discipline in Lipset's tradition does not imply to teach political science as a tranquillizer whose function is to destroy political enthusiasm. Political science has to distinguish between the naïve hope that our discipline can be used as a textbook for successful revolutions - and, at the same time, keeping the expectation alive, that knowledge of political reality 
as taught by political science can be favourable for political innovations, for evolution. Lipset's tradition must not be misunderstood as the recommendation for extinguishing partisan political activity. Lipset's tradition is not a recommendation at all. It is a general academic warning signal: Political science has to keep its sobriety; it has to accept any academically observed as well as any empirically proven and analyzed evidence which may contradict personal political preferences.

Austrian political science may be allowed to enjoy the fruits of being part of the academic establishment. The discipline, after its beginning as an outsider, has been structurally mainstreamed. This may take care of the dilemma a new discipline had to confront at its beginning: fighting for academic recognition by creating too much enthusiastic expectation among the forces of political innovation - and too much anxious fear among the forces defending the status quo.

\section{Objectivity and Political Neutrality - Do they exist?}

Is political science an "objective" discipline? Is its basic rule political "neutrality"? The answer is, of course, yes and no. Starting with the no: Social sciences in general and political science in particular can only fulfil their basic function of "enlightenment" under the conditions of political liberty. Seen from all the experience we have, democracy and the rule of law provide the only institutional framework which guarantees the kind of necessary freedom for observing, analyzing and evaluating all things political. The freedom of political science will always be among the first victims of authoritarian tendencies. The incompatibility of authoritarianism and political science is evident: Political science is and has to be very partisan when it comes to the essential question of political freedom and the rule of law.

But within the borders which define democratic freedom and the rule of law, political science has to be beyond partisanship. How many urban and highly educated women of the age group between 20 and 30 voted for Emanuel Macron in 2017? This must be correctly observed and described - completely independent from the observer's personal political leaning. What such an observation would imply for the French president's domestic and European reform agenda, must be (based on the level of already existing empirical knowledge) discussed freely - and, again, independently form personal preferences. In that respect, political science has to be "objective", has to be "neutral".

However, there will never be an undisputable understanding where the borderline is - between the discipline's necessary political partisanship and its also necessary objectivity, its political neutrality. There will always be the question, not possibly be answered in a neutral way, why the human rights situation in Israel and not the human rights situation in China is the focus of a specific research project. Political science, a political science department, a specific political scientist cannot focus on everything with the same intensity. But we must be prepared to answer questions - e.g. why Israel, and why not China?

The discourse concerning the always shifting borders is in itself helpful: Political scientists have to justify where they are positioning themselves in the multi-polar field between naïve strict "objectivity" and self-destroying pure partisanship. For the value of this discourse, international networking is important: How is the very same debate going on among Latin American political scientists? What can be learned from the similar discussions in India or in South-Africa, regarding the status of political science between pre-academic interests and academic respectability and quality?

Political science has to be transnational: Austria is not an island - and Austrian political scientists, in the very interest of their own qualification, have to be political scientists first; and, perhaps, Austrians or Europeans second. The international outlook helps to stabilize the discipline: The danger of becoming involved in daily routine politics on one side and the danger of neglecting the need to defend the basic values of an open society on the other side have to be observed and balanced - by Japanese political science and by Mexican political science. The Austrian situation will never be completely specific.

It also may help to keep in mind ongoing similar debates in other disciplines - e.g. (and especially) in economics. Economics, like political science, is confronted by the need to analyze and to evaluate policies - policies of a government, policies of a central bank; and policy proposals from an opposition party as well as policy recommendation from colleagues coming from the same discipline. Economics (and, more or less, all the other social sciences) will always be accused from opposite sides - to be "too political" or not being political at all. The objectivity-question is not raised concerning political science alone. And the comparison with other disciplines, how they deal with the standards between political partisanship and political neutrality, can make the self-reflection of political science easier.

A permanent danger which may be specific to political science is the always existing possibility of a conviction bias. As a major motivation to become a political scientist is an ardent interest in politics, political scientists may tend to be more influenced by personal political convictions than other social scientists. For that reason, the discipline has to be seen as a method of conviction control - and not as an instrument to look for more and more arguments in favour of an already existing conviction. Political science has to be always eager to de-construct "ideologies" in the tradition of 
Karl Mannheim (1936) and Hannah Arendt (195I). The possibility that a strict conviction becomes an ideology and, further on, becomes a totalitarian utopia (dystopia) is one aspect political scientists have always to be aware of. A specific conviction bias may - if unchecked - be just the beginning of the discipline's decline on a slippery slope.

\section{One among the others - Political Science als a Social Science Discipline}

Sociology and social psychology, economics and political philosophy must never be completely separated from political science's sensitivity. All academic disciplines dealing with society at large or with specific spheres of a society (like media consumption, like consumers' behaviour) are never far away from political science. Political science has to accept its role as one among others within the family of social sciences.

It is sociology especially, which does not really allow defining a consistent and strict difference to political science. What sociologists call "political sociology" is more or less what is our discipline. Electoral research can be defined as a sociologists' matter - or as an affaire political scientists have to define and to control. The impact family structures have on the society is, of course, to be analyzed by sociologists. But when it comes to gender roles within families and their consequences for political attitudes and behaviour, then political science is affected, too. And, of course, in all aspects of methodology we cannot distinguish between methods for sociologists - and methods for political scientists.

Sociology is like a parent ship: It is the core discipline of all social sciences. The other disciplines, political science among them, are extensions, in their autonomy explainable because of the particular complexity of specific social fields - like the economy, like politics. The realm of sociology is what has not (yet?) become a specialized social science discipline. The degree of specialisation differs - from period to period, from region to region. But all social science disciplines have in common the task to answer one central question - how can human behaviour explained, within society?

Political science in Austria is especially overlapping with the discipline of education - in that respect again following more or less the (West-) German example. After 1945, political education ("Politische Bildung") was seen as a central instrument to prevent the return of the dreadful past ("re-education"). Political education, based on knowledge - and not on moralistic preaching, needs political science: Knowing how a parliament works, becoming aware of the unavoidability of party pluralism in any democracy, understanding the interrelationship between interests and ideas - this is what political sci- ence can provide for educators; for curricula; for students of any age group. For all these reasons, political science and education have to cooperate: without clearly defined borderlines between themselves.

Economics is another significant "sister"- discipline for political science. Political scientists need some basic economic knowledge - e.g. for the understanding of the depth and the nature of social cleavages and their respective impact on party systems as well as on electoral behaviour. Economists can profit from the political scientists' understanding of consociational networks and the institutions needed for bridge-building over basic conflicting (class-) interests. As economics is usually the longest existing and financially best established among social sciences, political science has to accept the role of the "smaller brother", convincing economics of the mutual value of inter-disciplinary cooperation.

Among all the fields of legal studies, International Law is a discipline (probably, possibly the only one) without clear borders to political science - specifically to International Relations, one of the three core subdisciplines of political science. As international law is not based on an undisputed central authority with the ability to implement norms and rules, international law - as expressed by the formula of the "normative power of reality" - has to deal with politics as it is; and not as it should be according the constitution of a sovereign state. What reality is. To answer this basic question of what reality is, International Law and political science have to cooperate.

The other discipline I see the most difficult to define any border-line for political science is Contemporary History. Everything what political scientists publish based on their research is also material concerning history. To describe how better educated "white" male voters in the age group above 50 years have voted in the US presidential elections in November 2017 becomes part of historical knowledge the moment the results are known. Political science may be (and must be) distinguished from history due to very different methodological traditions, but as history has become more influenced by methods developed by social sciences and political science has to deal with the impact of history and its narratives on politics today, there is a give-and-take between history and political science.

Hannah Arendt helps us to understand another greyzone between disciplines: Trained as a philosopher in Germany, she became (after her emigration to the US) one of the most influential academics in the field of contemporary political theory. This of course did not mean that she had exchanged one discipline for another. It does not make sense at all to discuss whether she was a philosopher, or a political philosopher, or - according to the understanding of political science - a political theorist. She was (and is) Hannah Arendt, reminding us per- 
manently not to leave experience-based knowledge for the wonderland of speculation.

Political scientists must always keep in mind Hannah Arendt's famous dictum: "What is the subject of our thought? Experience! Nothing else!" (Arendt in Hill 1979, 308)

\section{Just an Umbrella - above rather Independend Disciplines?}

Political scientists generally agree that their discipline consists of three main branches: Political Theory, Political System(s), International Relations (IR). This consensus has been reached over the decades - not because there wouldn't be potentially different structural principles. But it makes sense to stick with this world-wide mainstream understanding more or less represented by the international representatives (like the International Political Science Association) and the main institutions of the discipline. Textbooks - like the 2016 edition of Lauth's and Wagner's introduction to political science (Lauth/Wagner 2016) - reflect this systematic approach, adding to the trias of theory, system and IR a broad reference to methodology.

Despite the tentative vagueness of the distinction between political science and other disciplines, the problem, which sometimes arises, is not so much the dispute about what is part and what is not part of the discipline. It is the debate whether political science can be seen as one discipline - and not consisting of more or less independent sub-disciplines. This can be even seen in the structural arrangements that some universities follow: At the Central European University - just to refer to one example - International Relations is a separate department; the department of Political Science consists of Political Theory and Comparative Politics.

Such tendencies are the result of specialisation. Like sociology as the social sciences' core discipline had to coexist with other social science disciplines, we cannot exclude the possibility of a trend the different branches of political science will be moving more and more apart from each other, away from political science as such, becoming step by step disciplines of their own. Of course, specialization happens. Political science could become a lose umbrella not any more uniting de facto or even formally independent new disciplines. This, per se, would be neither good nor bad.

But for the foreseeable future, political science should insist that it is a discipline - and not just a vague headline above different disciplines. It makes sense, that an expert in European integration identifies with political science in general; and that someone who has published on John Rawls and his "theory of justice" should be interested, probably more than the average citizen, how the results of electoral research explain the outcome of parliamentary elections in Italy. Nevertheless: The three main branches of the discipline have developed an understanding of their own, which can summarily be described:

- Political Theory, including the history of political thoughts - but always with the reference to contemporary politics, like Aristotle in Robert Dahl's approach to the understanding democracy as the absence of tyranny.

- Political Systems in their comparative dimension (with national or regional special cases - like Austrian politics for Austrian political scientists) - taught by emphasizing the distinction of functions and structures as well as processes and institutions.

- International Relations (and the grey-zones visà-vis political systems, when it comes e.g. to the European Union) - making use of the need of International Law to look for political facts as one source of legitimacy.

Respecting the autonomy of these branches, the common basis of the whole discipline should not be lost. Just as an example: Thomas Hobbes' theory - the concept of the "Leviathan" - offers a complex challenge to International Relations, as it does for the understanding of contemporary democracies. Hobbes may have a lot to say regarding Samuel Huntington's "Clash of Civilisation" as well as concerning Francis Fukuyama's "End of History". For that reason, all political scientists should be familiar with Thomas Hobbes' writing - those who are analyzing inter-state conflicts and those who describe present trends in contemporary party systems as well as in economic policies (Macpherson 1989).

A political scientist may have special expertise in one part of those three branches. But it makes sense to expect anyone who is qualified in political science to teach an undergraduate course à la "Introduction to Political Science" - and not only a specialized class e.g. on the US-Chinese relationship. Political science as a discipline should keep its corporate identity - beyond legitimate specialisation within the discipline.

The present stage of the discipline's structure - more or less defined by its three branches - is, of course, not final. The discipline will develop. Some significant aspects of specific developments and growing interests have been seen during the last decades of the late and the first two decades of the present century: The establishment on identity-focused interdisciplinary fields of studies in which political science plays a significant role. One example is "Black" (especially African American) Studies; another one is Jewish Studies; a third one Gender Studies.

Identity-based studies direct (or re-direct) the focus of social sciences towards segments of society that (in 
most cases forvery understandable reasons) feel neglected from the academic mainstream. It is kind of structural affirmative action, allowing underrepresented segments, overlooked by traditional research and teaching, to achieve more recognition. There does not seem to be any reason to oppose such tendencies. There are many reasons to be in favour of them. Nevertheless, ambivalent consequences must be recognized: Identity-based studies are cross-cutting through established disciplines and studies. The result can be positive, seen from the motivation of these studies - to be more accepted within the established academic system. But the result can also be a negative one - enshrined marginalization in form of academic isolation, of an academic ghetto. Anyway: Political science is well advised to take the efforts behind identity studies seriously - and to claim the discipline's potential core role in all these interdisciplinary fields.

\section{Political Science - its Basic Function}

Political science has an academic function - to be as good as academic standards require and to fulfil the qualitative expectations defined by the discipline's peers worldwide. Academically, political science has to work for its improvement: not to do this means deterioration. We have to be self-critical, we have to be self-reflexive: in that respect like any other academic discipline.

We have also to accept the challenges of interdisciplinarity - as Philipp Decker, David F.Campbell and Jürgen Braunstein (2018) explain in their study included in this special issue. Political science has to live up to the standards that permit discourse and cooperation with other disciplines. There is no place for "splendid isolation": We should learn from others - and we should enable others to learn from us. To improve our academic quality through permanent contacts with others - other disciplines, other departments, in other countries: this is the very essence of our academic function.

But political science has a political function as well. Political science's field is politics. The results of our research refer to politics. Political science teaching has an impact on politics - especially on the level of political understanding in the society at large. Political science can provide political advice for the business of politics. It can sharpen the understanding of journalism. It can motivate citizens to become politically active. Political science's political business is political enlightenment. Enlightenment - based on the rational tradition of René Descartes, Baruch Spinoza, John Stuart Mills, and Gottfried Leibniz (and not so much on the tradition of "idealism"). Enlightenment - translated into the contemporary world.

Enlightenment - based on experience: Anyone may have excellent ideas about "what should be done". But a normative concept of politics can only be implemented when it is allied to a political strategy, based on empirical evidence.

Enlightenment - against the forces of irrationality: Experience tells us (and, more specifically, the experience from $2 \mathrm{O}^{\text {th }}$ century's most terrible first half) what consequences political ideas may have; ideas not based on experience but on wishful thinking.

Enlightenment - directed against the forces of proto-totalitarianism: The totalitarian systems Hannah Arendt has analyzed may be dead, buried in the ruins of Berlin 1945 and in the disillusionment of Moscow I99I. But the temptation to force upon society a system which neglects the checks and balances necessary for an open society is still there and can be, must be observed by our discipline.

Enlightenment - as an early warning system: Based on empirically based evidence, our discipline must be a strong voice when the quality of democracy and the rule of law are in danger. Our discipline must be a credible voice, due to its academic quality.

Enlightenment - as a step not towards perfection, but to the lesser evil: The very idea of a perfect society, of a utopia leads to dystopia. The enemy of evil political science has to promote is the lesser evil.

Political enlightenment must not create illusions - it has to de-construct them. Political science is not a set of beliefs. To study political science, to be active in the academic discipline political science does not imply that we are approaching "the truth". "Truth" is too much connected with metaphysics. Discussing truth may be the task of a divinity school. Political science must be more modest. We don't offer last answers about any kind of truth. Political science is about reality - reality to be seen as the conclusive result of ongoing political research; reality - which, in the tradition of Karl Popper can (and always has to) be checked and re-checked.

This is enough of an intellectual burden, enough of an academic (and political) task for our discipline.

\section{References}

Arendt, Hannah (195I), The origins of Totalitarianism, New York: Harcourt Brace Jovanovich.

Berelson, Bernard/Paul Lazarsfeld/William McPhee (2017), Democratic Practice and Democratic Theory, in: Peter Bachrach (ed.), Political Elites in a Democracy, London: Routledge, 27-48.

Bluhm, William T. (1973), Building an Austrian Nation: The Political Integration of a Western State, New Haven: Yale University Press.

Dahl, Robert A. (1989), Democracy and Its Critics, New Haven: Yale University Press. 
Decker, Phillipp et al. (2018), Interdisciplinarity as a Source of Relevance for Political Science, in: ÖZP Austrian Journal of Political Science, Vol. 47(3), 19-32.

Gerlich, Peter/Helmut Kramer (1969), Abgeordnete in der Parteiendemokratie. Eine empirische Untersuchung des Wiener Gemeinderates, Wien: Verlag für $\mathrm{Ge}-$ schichte und Politik.

Hill, Melvyn A. (ed.) (I979), Hannah Arendt: The Recovery of the Public World, New York: St.Martin's Press.

Jahoda, Maria/Paul F. Lazarsfeld/Hans Zeisel (1933), Die Arbeitsloden von Marienthal. Ein soziographischer Versuch über die Wirkungen langdauernder Arbeitslosigkeit, Leipzig: Hirzel.

Lauth, Hans-Joachim/Christian Wagner (eds.) (2016), Politikwissenschaft: Eine Einführung, 8.Auflage, $\mathrm{Pa}-$ derborn: Schöningh.

Lehmbruch, Gerhard (1967), Proporzdemokratie. Politisches System und Politische Kultur in der Schweiz und in Österreich, Tübingen: C.Mohr.

Lichtenberger, Eva (2018), Building bridges between research on politics and political action, ÖZP-Austrian Journal of Political Science, Vol. 47(3), 65-68.

Lipset, Seymour Martin (198I), Political Man. The Social Bases of Politics, Baltimore: Johns Hopkins University Press.

Macpherson, C.B. (1989), The Political Theory of Possessive Individualism. From Hobbes to Locke, Oxford: Oxford University Press.

Mannheim, Karl (1936), Ideology and Utopia, London: Routledge.

Naßmacher, Karl-Heinz (I968), Das österreichische Regierungssystem. Große Koalition oder alternierende Regierung, Opladen: Westdeutscher Verlag.

Powell, Jr., G. Bignham (1970), Social Fragmentation and Political Hostility: An Austrian Case Study, Stanford: Stanford University Press.

Schumpeter, Joseph A. (I950), Capitalism, Socialism, and Democracy, New York: Harper and Row.

Senn, Martin/Franz Eder, Cui Bono Scientia Politica? A Multi-Dimensional Concept of Relevance and the Case of Political Science in Austria, in: ÖZP - Austrian Journal of Political Science, Vol. 47(3), I-I8.

Sowell, Thomas (20I3), Intellectuals and Race, New York: Basic Books.

Steiner, Kurt (1972), Politics in Austria, Boston: Little, Brown \& Co.

Stiefbold, Rodney/Dwaine Marvick (1966), Wahlen und Parteien in Österreich: Österreichisches Wahlhandbuch, Wien: Österreichischer Bundesverlag, Verlag für Jugend und Volk.

Stourzh, Gerald (2009), Spuren einer intellektuellen Reise: Drei Essays, Vienna: Böhlau.

\section{Author}

Anton Pelinka, 1975 - 2006 Professor of Political Science, University of Innsbruck; 2006 - 2018 Professor of Nationalism Studies and Political Science, Central European University, Budapest. Most recent book publication: "Die gescheiterte Republik. Politik und Kultur in Österreich, I9I8 - I938” (Böhlau - Vienna, 20I7) 